\title{
ビスフォスフォネート投与と関連性があると考えられた 顎骨骨髄炎ならびに顎骨壊死に関する調查
}

\author{
島原政司 ${ }^{1)}$ ·有吉靖則 ${ }^{1)}$ ・今井 裕 ${ }^{2)}$ \\ 水城春美 ${ }^{3)}$. 嶋田 淳 ${ }^{4)} \cdot$ 古澤清文 ${ }^{5)}$ \\ 森田章介 ${ }^{6)} \cdot$ 上山吉哉 ${ }^{7)}$
}

\section{A survey of bisphosphonate-related osteomyelitis/ osteonecrosis of the jaws}

\author{
SHIMAHARA Masashi ${ }^{1)} \cdot$ ARIYOSHI Yasunori $^{1)}$ \\ IMAI Yutaka ${ }^{2)} \cdot$ MIZUKI Harumi $^{3)}$ \\ SHIMADA Jun ${ }^{4)} \cdot$ FURUSAWA Kiyofumi $^{5)}$ \\ MORITA Syosuke $^{6)} \cdot$ UEYAMA Yoshiya $^{7)}$
}

\begin{abstract}
Bisphosphonates are used for the management of bone metastatic disease and hypercalcemia caused by malignancy, as well as the treatment of osteoporosis. Recently, a number of patients with bisphosphonate-associated osteomyelitis and osteonecrosis of the jaws have been reported in the English-language literature. This report describes patients with bisphosphonate-related osteomyelitis and osteonecrosis of the jaws in Japan. The subjects were enrolled using questionnaires sent to 239 institutions certified as training facilities by the Japanese Society of Oral and Maxillofacial Surgeons in 2006. Thirty patients (4 men and 26 women) from 18 different institutions (mean age at diagnosis, 66.9 years) were studied. As for local features, pain with or without swelling was the most common symptom and sign. The mandible was affected in 22 patients, the maxilla in 6 , and both jaws in 2. Twenty patients received intravenous bisphosphonates, 8 received only oral bisphosphonates, and 1 received both types of treatment. The reasons for bisphosphonate treatment were bone metastasis from breast carcinoma (13 patients), multiple myelomas (6 patients), osteoporosis (8 patients), and hypercalcemia related to malignancy. More than $50 \%$ of the patients underwent oral surgery including tooth extraction just before or during treatment with bisphosphonates, while 5 patients received no dental treatment. In addition to antibiotic therapy, surgery, including sequestrectomy and curettage, was performed. As for outcome, 8 of the patients were completely cured, while 17 patients remained under treatment at the time of this writing.
\end{abstract}

Key words: bisphosphonate（ビスフォスフォネート），osteonecrosis（骨壊死），osteomyelitis（骨髄炎），jaw bones (顎骨)，bone metastasis（骨転移）

1) 大阪医科大学応用外科学講座口腔外科学教室 (主任：島原政司教授)

2) 獨協医科大学口腔外科学講座

(主任：今井 裕教授)

3) 岩手医科大学歯学部口腔外科学第一講座 （主任：水城春美教授）

4) 明海大学茵学部病態診断治療学講座口腔嵿顔面外科学第一 （主任：嶋田 淳教授）

5) 松本歯科大学口腔顎顔面外科学講座 (主任：古澤清文教授)

6) 大阪菌科大学曾学部口腔外科学第一講座 （主任：森田章介教授）

7) 山口大学医学部特殊専門領域腫瘍病態学講座 (主任：上山吉哉教授)

${ }^{1)}$ Department of Dentistry and Oral Surgery, Division of Surgery 2, Osaka Medical College (Chief: Prof. SHIMAHARA Masashi)
${ }^{2)}$ Department of Oral and Maxillofacial Surgery, Dokkyo University School of Medicine (Chief: Prof. IMAI Yutaka)

${ }^{3)}$ First Department of Oral and Maxillofacial Surgery, School of Dentistry, Iwate Medical University (Chief: Prof. MIZUKI Harumi)

${ }^{4)}$ Division of First Oral and Maxillofacial Surgery, Department of Diagnosis and Therapeutics, Meikai University School of Dentistry (Chief: Prof. SHIMADA Jun)

${ }^{5)}$ Department of Oral and Maxillofacial Surgery, Matsumoto Dental University (Chief: Prof. FURUSAWA Kiyofumi)

${ }^{6)}$ First Department of Oral and Maxillofacial Surgery, Osaka Dental University (Chief: Prof. MORITA Syosuke)

${ }^{7)}$ Department of Oral and Maxillofacial Surgery, Yamaguchi University of Medicine (Chief: Prof. UEYAMA Yoshiya)

受付日：2007年 7 月 2 日

採択日：2007年 7 月 24 日 
緒

ビスフォスフォネート（以下，BP と略す）は，悪性腫瘍 の骨転移に関連する骨吸収の阻害，高カルシウム血症の治 療ならびに骨粗鬆症の治療に有益な薬㓱で，医科の臨床で 頻用されている. 一方， 2003 年に BP 投与中の患者におい て，顎骨壊死症例が報告され ${ }^{1 ， 2)}$ ，本邦においても同様の 㖽骨壊死が生じたことが報告されている ${ }^{3,4)}$ 。その発症原 因として，抜柬などの侵襲的蒾科治療が挙げられており， 茵科医は，その発生の現状ならびに初発症状などの詳細に つき把握する必要があると考える。

本調査の目的は，本邦における BP 投与中に生じた顎骨 骨髄炎ならびに颤骨壊死の現状を把握し，その臨床症状， 経過, 㐘科治療との関連性, 転帰を明らかにすることである.

\section{対象ならびに方法}

本調查は，社団法人日本口腔外科学会指定研修機関（以 下，指定機関と略す）を対象に，2006 年度（社）日本口腔 外科学会調査企画委員会（島原政司委員長，今井 裕副委 員長, 水城春美委員, 嶋田 淳委員, 古澤清文委員, 森田章 介委員，上山吉哉委員）の事業の一環として施行された。 すなわち，第 1 次調查として 2006 年 4 月に全国の指定機 関 239 施設に BP が原因と考えられる顎骨骨髄炎ならびに 㖽骨壊死が疑われる症例に関してアンケートを実施した。 そのなかで，「あり」，と回答した施設を対象に，第 2 次調 查として 9 月にその詳細について再度郵送にて調查を実施 した．調查票より得られたデータをデータベース化し，年 齢，性別，臨床症状，画像診断所見，過去の顎骨への放射線 治療の有無，抗癌剤ならびに副腎皮質ステロイド剤の投与 の有無, 口腔衛生状態, 投与された BP の種類（表 1), BP 投与開始より顎骨病変発現までの期間，BP の使用理由， $\mathrm{BP}$ 投与前後の歯科処置, 顎骨病変に対する処置, 使用され た抗菌薬の種類，ならびに転帰について分析を行った。

臨床症状として，局所の疼痛ならびに腫脹に関しては， その有無，さらにその他の顎骨の所見について記載があっ たものを集計した。画像診断所見としては，アンケート用 紙は選択肢を設けずに記載する様式のため，それらの所見 を腐骨形成像, 骨吸収像, 骨硬化像, 虫食い像, 所見なし, その他の 6 型に分類し，記載された所見と最も類似する所 見を採択した.

投与された BP の種類は，経口薬，注射薬に分け，さらに 薬剂別に集計を行った。複数の BP 系薬剤の投与歴がある 場合には，それぞれの薬剤投与歴ありに含めた。投与開始 から症状発現までの期間は，BP 系薬剂の種類にかかわら ず，注射ならびに経口投与の開始時から当該事象（投与中
止または症状発現）が生じるまでの期間とした。投与期間 中に薬剤の変更が行われた症例においては，投与期間はそ れぞれの薬剤投与の合計期間とした.

BP の使用理由は，骨転移（乳癌，多発性骨髄腫，前立腺 癌, その他), 高カルシウム血症, 骨粗鬆症, その他の選択 肢を設けた。

顎骨病変に対する処置は，抗菌薬投与，外科的処置，高 圧酸素療法，その他の項目を設け，さらに抗菌薬が投与さ れた場合には，その種類を調査した。

転帰としては，治癒，治療中，治療不能，進行，未治療， 不明の選択肢を設けた。さらに治癒した場合には，容易に 治癒, 難渋の項目を設けた。

結果

\section{BP 投与と関連すると考えられる顎骨骨髄炎・ 骨壊死の症例数, 性, 年齢, 罹患顎骨について}

$\mathrm{BP}$ による顎骨病変の有無に関する 1 次アンケートを施 行し，153 施設より回答を得た。 そのなかで，25施設より 41 例の顎骨骨髄炎・顎骨壊死ありとの結果が得られた. 25 施設に 2 次アンケートを郵送し，18 施設より 32 症例の詳 細が得られたが，2症例においては碩骨病変の記載がない ため検討対象から除外し，30症例を対象に検討を行った（表 2).

30 症例の内訳は, 男性 4 例, 女性 26 例（男女比 $=1$ : $6.5)$, 平均年齢は 66.9 歳（範囲：48～99 歳）であった. 罹患顎骨は，上顎骨のみが 6 症例 $(20.0 \%)$, 下顎骨のみが 22 症例 $(73.3 \%)$ ，上下顎骨が 2 症例（6.7\%）であった (表 3).

\section{2. 臨床症状，画像診断所見，顎骨への放射線治療 の有無，併用薬刘，口腔衛生状態について（表 3)}

茵科口腔外科施設を受診した際の臨床症状として, 疼痛 が 23 症例 $(76.7 \%)$ ，腫脹が 21 症例 $(70.0 \%)$ と大半の 症例に認められた。その他, 排膿が 9 症例 $(30.0 \%)$, 知覚 麻痺が 4 症例 $(13.3 \%)$, 出血が 3 症例（10.0\%）に認め られた。 な扮，初診時に骨露出が認められた症例は 19 症例 (63.3\%) であった.

画像診断所見としては，腐骨形成像が 9 症例 $(30.0 \%)$, 骨吸収像が 7 症例 $(23.3 \%)$ ，虫食い像が 4 症例（13.3\%） に認められた。なお，その他の所見として，抜蒾窩の骨の 形成不全，骨髄炎を疑わせる像，当該部位に存在する菌の 破折像，脱落蔝の柬槽硬線の肥厚像がそれぞれ 1 症例に認 められた.

顎骨への放射線治療の既往の有無に関しては，全症例と もに照射の既往はなかった。 
表 1 現在, 本邦で使用されているビスフォスフォネート製剤

\begin{tabular}{|c|c|}
\hline 注 射 薬 & 経 口 薬 \\
\hline $\begin{array}{c}\text { ・アレンドロン酸ナトリウム水和物 } \\
\left.\text { (オンクラスト }{ }^{\circledR}, \text { テイロック }{ }^{\circledR}\right)\end{array}$ & $\begin{array}{c}\text { ・アレンドロン酸ナトリウム水和物 } \\
\left.\text { (フォサマック }{ }^{\circledR}, \text { ボナロン® }{ }^{\circledR}\right)\end{array}$ \\
\hline $\begin{array}{l}\text { ・インカドロン酸ナトリウム } \\
\text { (ビスフォナール®) }\end{array}$ & $\begin{array}{l}\text { ・チヂロン酸ナトリウム } \\
\text { (ダイドロネル®) }\end{array}$ \\
\hline $\begin{array}{l}\text { ・ゾレドロン酸水和物 } \\
\text { (ゾメタ®) }\end{array}$ & $\begin{array}{c}\text { ・リセドロン酸ナトリウム水和物 } \\
\text { (アクトネル® }{ }^{\circledR} \text { ，ベネット®) }\end{array}$ \\
\hline $\begin{array}{l}\text { ・パミドロン酸ナトリウム } \\
\text { (アレディア }\end{array}$ & \\
\hline
\end{tabular}

表 2 施設名と症例数

\begin{tabular}{lc}
\hline \multicolumn{1}{c}{ 施 設 名 } & 症例数 \\
\hline 岩手医科大学附属柬科医療センター & 2 \\
NTT西日本大阪病院 & 1 \\
大阪医科大学病院 & 2 \\
大阪大学歯学部附属病院 & 4 \\
大阪府済生会千里病院 & 1 \\
京都大学医学部附属病院 & 2 \\
近畿大学医学部附属病院 & 1 \\
国立国際医療センター & 4 \\
社会福祉法人函館厚生院函館五稜郭病院 & 1 \\
社会保険船橋中央病院 & 1 \\
鶴見大学歯学部付属病院 & 1 \\
東京医科大学病院 & 1 \\
長崎大学医学部・歯学部付属病院 & 1 \\
名古屋大学医学部付属病院 & 1 \\
兵庫医科大学病院 & 2 \\
北海道大学病院歯科診療センタ一 & 3 \\
横浜市立大学付属病院 & 1 \\
和歌山県立医科大学付属病院 & 1 \\
\hline
\end{tabular}

施設名は50音順, 病院単位で集計

同時に服用されていた薬凨が記載されていた症例は 22 症例で，抗癌薬ならびに副腎皮質ステロイド薬がそれぞれ 10 症例, 4 症例に投与されていた.

口腔衛生状態は，普通と診断された症例が 17 症例 (56.7\%) と多く, 不良, 良好はほぼ同症例数であった.

\section{3. 投与された BP ならびに投与期間について} (表 4)

投与された BPは，パミドロン酸ナトリウム水和物（注 射薬）が 16 症例 $(53.3 \%)$ と最も多く，インカドロン酸 ナトリウム (注射薬) が 9 症例 $(30.0 \%)$ ，アレンドロン 酸ナトリウム水和物（経口薬）が 8 症例 $(26.7 \%$ ) と続い た。投与経路別には，注射薬のみの投与が 20 症例
$(66.7 \%)$, 経口薬のみの投与が 8 症例 $(26.7 \%)$, 両者とも に投与された症例が 1 例 $(3.3 \%)$, 記載されていなかった 症例が 1 症例であった。

投与開始から発症までの平均期間は 26.5 か月（範囲：3 〜 68 か月）であった。

投与経路別には，注射薬のみ投与の症例においては，投 与期間は平均 25.7 か月（範囲：3〜 59 か月), 経口薬のみ 投与の症例に扣いては 28.5 か月（範囲：3〜 68 か月）で あった。

\section{BP 投与中または投与直前の歯科治療につい \\ て（表 4)}

対象症例の柬科治療に関しては，歯科治療歴ありが 19 症例 $(63.3 \%)$ ，なしが 5 症例 $(16.7 \%), 6$ 症例において は記載されていなかった。柬科治療の内容は, 抜柬が 16 症 例 $(53.3 \%)$ と最も多く，その他，インプラント体埋入, 義蒾装着, ブリッジ装着, 根管治療, う蝕処置があった.

\section{BP の使用理由について（表 4)}

$\mathrm{BP}$ の使用理由は, 乳癌の骨転移が最も多く 13 症例 (43.3\%) であった。 その他，骨粗鬆症 8 症例 $(26.7 \%)$, 多発性骨髄腫 6 症例 $(20.0 \%)$ と続いた。

\section{6 . 顎骨病変に対する処置ならびに転帰について} (表 4)

抗菌薬の投与に関して記載されていなかった 4 症例を除 いた 26 症例に，抗菌薬の投与が行われていた. 使用薬剂 は, $\beta$ ラクタム系抗菌薬, 二ューキノロン系抗菌薬を投与 された症例が多かった。

外科的処置が行われた症例は 17 症例 $(56.7 \%)$ で，さ らに高圧酸素療法が施行された症例が 2 症例 (6.7\%) で あった，外科的処置の内容はさまざまで，腐骨除去が 9 症 例 $(30 \%)$ と最も多く, その他, 掻爬術, 少量の骨削除, 抜菌などが施行されていた。 なお, 病的骨折を生じた症例 
表 3 症例一覧

\begin{tabular}{|c|c|c|c|c|c|c|c|c|c|}
\hline 症例 & 性踢 & 年齢 & & & 骨露出 & 画像診断 & 靧 骨への & 併用薬剂（抗癌剤， & 口腔衛生 \\
\hline No. & 性斺 & 千䀧 & 惟忠部位 & 蛞不正㐸 & の有無 & 所 見 & 放治の有無 & ステロイド剤) * & \\
\hline 1 & 男 & 62 & 下 蘱 骨 & 疼痛 & なし & その 他 & なし & 抗癌剤 & 良好 \\
\hline 2 & 女 & 99 & 下 頑 骨 & 疼痛, 腫脹 & あり & その他 & なし & 不明 & 普通 \\
\hline 3 & 女 & 55 & 下 顎 骨 & 疼痛, 腫脹 & あり & 腐骨形成 & なし & 未記載 & 普通 \\
\hline 4 & 女 & 52 & 下 顎 骨 & 腫脹 & あり & 骨硬化像 & なし & 未記載 & 不良 \\
\hline 5 & 男 & 62 & 下 顗 骨 & 腫脹 & なし & 虫食い像 & なし & なし & 普通 \\
\hline 6 & 女 & 66 & 下 顎 骨 & 疼痛, 腫脹, 排膿 & なし & 腐骨形成 & なし & 抗癌㨈 & 良好 \\
\hline 7 & 女 & 50 & 上顎 骨 & 疼痛，腫脹 & なし & 骨吸収像 & なし & 不明 & 良好 \\
\hline 8 & 女 & 70 & 上下顎骨 & 疼痛, 腫脹, 出血 & なし & 骨吸収像 & なし & 抗癌剂 & 普通 \\
\hline 9 & 女 & 63 & 下 顎 骨 & 疼痛，腫脹，排膿 & なし & 骨吸収像 & なし & 抗癌剂 & 普通 \\
\hline 10 & 女 & 69 & 下 頦 骨 & 疼痛, 腫脹, 排膿, 知覚麻痺 & あり & 腐骨形成 & なし & 抗癌㨈 & 普通 \\
\hline 11 & 女 & 62 & 下 顎 骨 & 排膿，知覚麻痺 & なし & 腐骨形成 & なし & ステロイド剤 & 普通 \\
\hline 12 & 女 & 84 & 上 顎 骨 & 疼痛, 排膿 & あり & 腐骨形成 & なし & 未記載 & 普通 \\
\hline 13 & 女 & 62 & 下 顎 骨 & 疼痛, 腫脹, 知覚麻痺 & あり & 腐骨形成 & なし & 未記載 & 普通 \\
\hline 14 & 女 & 71 & 上 顎 骨 & 疼痛, 腫脹 & あり & 未記載 & なし & ステロイド剂 & 普通 \\
\hline 15 & 女 & 76 & 上 顎 骨 & 疼痛, 腫脹 & あり & 虫食い像 & なし & なし & 良好 \\
\hline 16 & 女 & 68 & 下 嵿 骨 & 疼痛 & なし & 所見なし & なし & 未記載 & 普通 \\
\hline 17 & 女 & 62 & 下 顎 骨 & 疼痛 & あり & 骨吸収像 & なし & 抗癌剤 & 不良 \\
\hline 18 & 女 & 70 & 下顎 骨 & 疼痛, 腫脹 & あり & 骨硬化像 & なし & なし & 良好 \\
\hline 19 & 女 & 64 & 下 顎 骨 & 疼痛, 知覚麻痺 & あり & 骨吸収像 & なし & ステロイド剂 & 普通 \\
\hline 20 & 女 & 65 & 下顎 骨 & 腫脹 & あり & その他 & なし & なし & 不良 \\
\hline 21 & 女 & 64 & 上㖽 骨 & 腫脹, 排膿 & あり & 骨吸収像 & なし & 未記載 ～～～～～ & 良好 \\
\hline 22 & 男 & 59 & 下 顎 骨 & 疼痛 & あり & 腐骨形成 & なし & 抗癌剤, ステロイド剤 & 普通 \\
\hline 23 & 女 & 67 & 下 顎 骨 & 疼痛, 腫脹, 出血 & なし & 所見なし & なし & なし & 普通 \\
\hline 24 & 女 & 72 & 下 䫁 骨 & 疼痛，腫脹 & あり & 骨吸収像 & なし & 抗癌剮 & 普通 \\
\hline 25 & 女 & 78 & 下 顎 骨 & 疼痛, 腫脹 & あり, なし & 虫食い像 & なし & なし & 不良 \\
\hline 26 & 女 & 73 & 下 顗 骨 & 疼痛, 腫脹 & あり & 腐骨形成 & なし & なし & 普通 \\
\hline 27 & 男 & 85 & 上 顎 骨 & 腫脹, 出血 & あり & 虫食い像 & なし & 抗癌剂 & 良好 \\
\hline 28 & 女 & 48 & 下 顎 骨 & 腫脹, 排膿 & なし & 未記載 & なし & なし & 不良 \\
\hline 29 & 女 & 54 & 上下顎骨 & 疼痛, 排膿 & あり & その他 & なし & 抗癌剂 & 不良 \\
\hline 30 & 女 & 75 & 下 顎 骨 & 疼痛, 排膿 & なし & 腐骨形成 & なし & なし & 普通 \\
\hline
\end{tabular}

* : 不明：アンケートに不明と記載されていたもの, 未記載：アンケートの併用薬剤の項に記載がなかったもの, なし：アンケートに併用薬剤は記載されていたが, 抗癌凨, ステロイド剤以外の薬剤のみであったもの

が 2 症例あり，区域切除がなされていた。

転帰は，治療中の症例が 17 症例 $(56.7 \%)$ と最も多か った。そのなかで，治療中であるものの，進行ならびに難 渋している症例がそれぞれ 3 症例であった．治癒した症例 は 8 症例 $(26.7 \%)$ であり，治癒が容易，難渋であったも のがそれぞれ 4 症例であった。治癒した症例のなかで， 7 症例において腐骨除去がなされていた。なお，5症例にお いては，転帰に関して不明または未記載であった。

\section{考察}

顎骨壊死はさまざまな原因で発生する可能性がある．柬 科臨床に扔いては，放射線治療後の顎骨壊死に遭遇する機 会は多い ${ }^{5)}$. 近年, BP 投与と関連性があると考えられる顎
骨壊死症例の報告が欧米において散見され ${ }^{6 \sim 9)}$ ，本邦に 抢いても症例報告がされつつある ${ }^{3 ， 4)}$ ，顎骨壊死は，その 契機として抜柬など侵襲的な菌科処置のみならず，茵周疾 患などが挙げられており ${ }^{7)}$, 日常蔝科臨床にて注意する必 要がある，そこで，本邦で BP と関連性があると考えられ る顎骨病変の発生状況を把握することが必要であると考 え，指定機関を対象に調查を行った。米国口腔顎顔面外科 学会では，2006 年 9 月に BP と関連性がある顎骨壊死に関 して，その定義，治療方針などについて公表している ${ }^{10)}$. そのなかで，顎骨壊死の定義として，(1)現在または以前に BP 系薬剤により治療を受けた既往がある, (2) 8 週間以上 継続する骨露出が䫟口腔領域にみられる，(3)顎骨に対する 放射線治療の既往がないこと，の 3 項目を挙げている. 今 後，妥当性を検討した上で，本邦においても診断基準を設 
表 4 投与されたビスフォスフォネート，原疾患，茵科処置の有無，治療，転帰（1）

\begin{tabular}{|c|c|c|c|c|c|c|c|c|}
\hline $\begin{array}{l}\text { 症例 } \\
\text { No. }\end{array}$ & 投与された BP & $\begin{array}{l}\text { 症状発現 } \\
\text { までの期 } \\
\text { 間（月） }\end{array}$ & BP投与理由 & $\begin{array}{l}\text { BP 投与前後の } \\
\text { 茵科処置 }\end{array}$ & $\begin{array}{l}\text { 顎骨病変に対 } \\
\text { する処置 }\end{array}$ & $\begin{array}{l}\text { 使用抗菌薬 } \\
\text { (投与経路) }\end{array}$ & 転帰 & 特記事項 \\
\hline 1 & パミドロン酸 & 3 & $\begin{array}{l}\text { 高カルシウム } \\
\text { 血症(肺癌) }\end{array}$ & 抜菌 & 掻爬 & セフェム（PO） & 治療中 & - \\
\hline 2 & アレドロン酸 (錠) & 24 & 骨粗鬆症 & なし & $\begin{array}{l}\text { 掻爬, } \\
\text { 高圧酸素療法 }\end{array}$ & カルバペネム（IV） & 治療中 & $\begin{array}{l}\text { 雬の自然脱 } \\
\text { 落後治癒不 } \\
\text { 全 }\end{array}$ \\
\hline 3 & パミドロン酸 & 22 & 骨転移(乳癌) & 拔柬 & $\begin{array}{l}\text { 掻爬, } \\
\text { 腐骨除去, } \\
\text { 皮質骨除去 }\end{array}$ & $\begin{array}{l}\text { セフェム }(\mathrm{PO}, \mathrm{IV}), \\
\text { マクロライド }(\mathrm{PO}), \\
\text { ニューキノロン }(\mathrm{PO})\end{array}$ & $\begin{array}{l}\text { 治癒 } \\
\text { (難溙) }\end{array}$ & $\begin{array}{l}\text { 治療中に病 } \\
\text { 的骨折し区 } \\
\text { 域切除術 }\end{array}$ \\
\hline 4 & インカドロン酸 & 14 & 骨転移(肺癌) & $\begin{array}{l}\text { 抜柬, 抜䯣, } \\
\text { う蝕処置 }\end{array}$ & 抜菌 & $\begin{array}{l}\text { セフェム (IV), ペニ } \\
\text { シリン (IV), アミノグ } \\
\text { リコシド }(\mathrm{IV}), \text { 二ュ } \\
\text { ーキノロン }(\mathrm{PO})\end{array}$ & 不明 & $\begin{array}{l}\text { 治療中に病 } \\
\text { 的骨折し区 } \\
\text { 域切除術 }\end{array}$ \\
\hline 5 & 記載なし & 不明 & 骨転移 & 未記載 & 未記載 & 不明 & 不明 & - \\
\hline 6 & $\begin{array}{l}\text { インカドロン酸 } \\
\text { ゾレドロン酸 }\end{array}$ & 28 & 骨転移(乳癌) & 抜柬 & 切開排膿処置 & $\begin{array}{l}\text { マクロライド }(\mathrm{PO}), \\
\text { ペニシリン }(\mathrm{PO})\end{array}$ & 治療中 & - \\
\hline 7 & パミドロン酸 & 不明 & 骨転移(乳癌) & 未記載 & 不明 & 不明 & 未記載 & - \\
\hline 8 & $\begin{array}{l}\text { パミドロン酸 } \\
\text { インカドロン酸 }\end{array}$ & 6 & 骨転移(乳癌) & $\begin{array}{l}\text { インプラント体 } \\
\text { 埋入 }\end{array}$ & 不明 & $\begin{array}{l}\text { ニューキノロン }(\mathrm{PO}), \\
\text { ペニシリン }(\mathrm{PO})\end{array}$ & 治療中 & - \\
\hline 9 & アレンドロン酸 & 3 & 骨転移(乳癌) & 抜菌 & 不明 & $\begin{array}{l}\text { ホスホマイシン (IV), } \\
\text { ペニシリン (PO), } \\
\text { セフェム }(\mathrm{PO})\end{array}$ & 不明 & - \\
\hline 10 & パミドロン酸 & 23 & 骨転移(乳癌) & 抜柬 & $\begin{array}{l}\text { 露出骨鋭縁削除 } \\
\text { (表面麻酔下) }\end{array}$ & ペニシリン（PO） & 治療中 & - \\
\hline 11 & リセドロン酸 (錠) & 3 & 骨粗鬆症 & なし & 腐骨除去 & $\begin{array}{l}\text { セフェム }(\mathrm{PO}), \text { 二ュ } \\
\text { 一キノロン }(\mathrm{PO})\end{array}$ & $\begin{array}{l}\text { 治癒 } \\
\text { (容易) }\end{array}$ & - \\
\hline 12 & インカドロン酸 & 31 & 骨粗鬆症 & 未記載 & 腐骨除去 & マクロライド（PO） & $\begin{array}{c}\text { 治癒 } \\
\text { (容易) }\end{array}$ & - \\
\hline 13 & インカドロン酸 & 59 & 骨転移(乳癌) & 未記載 & 腐骨除去 & マクロライド（PO） & 治療中 & - \\
\hline 14 & $\begin{array}{l}\text { パミドロン酸， } \\
\text { アレドロン酸 (錠) }\end{array}$ & 不明 & 多発性骨髄腫 & 抜茵, 根管治療 & $\begin{array}{l}\text { その他（外科的 } \\
\text { 消炎） }\end{array}$ & ペニシリン（PO） & $\begin{array}{l}\text { 治癒 } \\
\text { (難渋) }\end{array}$ & - \\
\hline 15 & アレドロン酸 (錠) & 27 & 骨粗鬆症 & 抜菌 & $\begin{array}{l}\text { 腐骨除去, 掻爬, } \\
\text { 上顎骨部分切除, } \\
\text { 高圧酸素療法 }\end{array}$ & $\begin{array}{l}\text { セフェム }(\mathrm{IV}), \\
\text { マクロライド }(\mathrm{PO})\end{array}$ & $\begin{array}{l}\text { 治癒 } \\
\text { (容易) }\end{array}$ & $\begin{array}{l}\text { 真菌性上顎 } \\
\text { 洞炎合併 }\end{array}$ \\
\hline 16 & アレドロン酸 (錠) & 18 & 骨転移(乳癌) & なし & 未記載 & テトラサイクリン（IV） & 治療中 & - \\
\hline 17 & $\begin{array}{l}\text { パミドロン酸 , } \\
\text { ゾレドロン酸 }\end{array}$ & 21 & 骨転移(乳癌) & 未記載 & 未記載 & ペニシリン（PO） & 未記載 & - \\
\hline 18 & $\begin{array}{l}\text { アレドロン酸 (錠), } \\
\text { エチドロン酸 (錠) }\end{array}$ & 68 & 骨粗鬆症 & 抜柬 & 掻爬術 & マクロライド（PO） & $\begin{array}{l}\text { 治療中 } \\
\text { (進行) }\end{array}$ & - \\
\hline 19 & パミドロン酸 & 13 & 多発性骨骾腫 & 抜柬 & 未記載 & マクロライド（PO） & $\begin{array}{l}\text { 治療中 } \\
\text { (進行) }\end{array}$ & - \\
\hline 20 & $\begin{array}{l}\text { パミドロン酸, } \\
\text { インカドロン酸 }\end{array}$ & 53 & 多発性骨髄腫 & $\begin{array}{l}\text { 抜茵, } \\
\text { 茵周治療, 義歯 }\end{array}$ & 未記載 & 不明 & $\begin{array}{c}\text { 治療中 } \\
\text { (ほぼ治癒) }\end{array}$ & - \\
\hline
\end{tabular}


表 4 投与されたビスフォスフォネート，原疾患，㐘科処置の有無，治療，転帰（2）

\begin{tabular}{|c|c|c|c|c|c|c|c|c|}
\hline $\begin{array}{l}\text { 症例 } \\
\text { No. }\end{array}$ & 投与された BP & $\begin{array}{l}\text { 症状発現 } \\
\text { までの期 } \\
\text { 間（月） }\end{array}$ & $\mathrm{BP}$ 投与理由 & $\begin{array}{l}\text { BP 投与前後の } \\
\text { 茵科処置 }\end{array}$ & $\begin{array}{l}\text { 顎骨病変に対 } \\
\text { する処置 }\end{array}$ & $\begin{array}{l}\text { 使用抗菌薬 } \\
\text { (投与経路) }\end{array}$ & 転帰 & 特記事項 \\
\hline 21 & $\begin{array}{l}\text { パミドロン酸, } \\
\text { インカドロン酸 }\end{array}$ & 38 & 多発性骨髄腫 & ブリッジ装着 & 腐骨除去 & マクロライド（PO） & $\begin{array}{l}\text { 治癒 } \\
\text { (難溙) }\end{array}$ & $\begin{array}{l}\text { 腐骨除去後, } \\
\text { 腐骨再発す } \\
\text { るも自然治 } \\
\text { 癒 }\end{array}$ \\
\hline 22 & パミドロン酸 & 26 & 多発性骨䯣腫 & 未記載 & 未記載 & $\begin{array}{l}\text { セフェム }(\mathrm{PO}), \text { ニュ } \\
\text { ーキノロン }(\mathrm{PO})\end{array}$ & $\begin{array}{l}\text { 治療中 } \\
\text { (難溙) }\end{array}$ & - \\
\hline 23 & パミドロン酸 & 46 & 多発性骨髓腫 & $\begin{array}{l}\text { 義柬作成，う蝕 } \\
\text { 治療 }\end{array}$ & 未記載 & $\begin{array}{l}\text { セフェム }(\mathrm{PO}), \text { テト } \\
\text { ラサイタリン }(\mathrm{PO})\end{array}$ & $\begin{array}{l}\text { 治療中 } \\
\text { (進行) }\end{array}$ & - \\
\hline 24 & $\begin{array}{l}\text { パミドロン酸 , } \\
\text { インカドロン酸 }\end{array}$ & 29 & 骨転移(乳癌) & 抜歯 & 未記載 & $\begin{array}{l}\text { カルバペネム (IV), } \\
\text { ペニシリン }(\mathrm{PO})\end{array}$ & $\begin{array}{l}\text { 治療中 } \\
\text { (難涉) }\end{array}$ & - \\
\hline 25 & アレドロン酸 (錠) & 15 & 骨粗鬆症 & 抜茵 & $\begin{array}{l}\text { 腐骨除去, 掻爬, } \\
\text { 下㓵骨辺縁切除 }\end{array}$ & $\begin{array}{l}\text { ペニシリン (IV), } \\
\text { セフェム (IV) }\end{array}$ & $\begin{array}{l}\text { 治癒 } \\
\text { (難渋) }\end{array}$ & - \\
\hline 26 & アレドロン酸 (錠) & 13 & 骨粗鬆症 & 抜歯 & $\begin{array}{l}\text { 腐骨除去, 下顎 } \\
\text { 骨辺縁切除 }\end{array}$ & 不明 & $\begin{array}{l}\text { 治瘉 } \\
\text { (容易) }\end{array}$ & - \\
\hline 27 & パミドロン酸 & 16 & 骨転移(乳癌) & なし & 骨削除(少量) & セフェム（PO） & 治療中 & - \\
\hline 28 & $\begin{array}{l}\text { パミドロン酸, } \\
\text { ゾレドロン酸, } \\
\text { インカドロン酸 }\end{array}$ & 35 & 骨転移(乳癌) & 抜歯 & 拔茵, 腐骨除去 & セフェム（PO） & 治療中 & - \\
\hline 29 & $\begin{array}{l}\text { パミドロン酸, } \\
\text { ゾレドロン酸 }\end{array}$ & 22 & 骨転移(乳癌) & なし & なし & $\begin{array}{l}\text { ペニシリン (PO ), } \\
\text { セフェム (IV) }\end{array}$ & $\begin{array}{l}\text { 治療中 } \\
\text { (難渋) }\end{array}$ & $\begin{array}{l}\text { 柬の自然脱 } \\
\text { 落後治癒不 } \\
\text { 全 }\end{array}$ \\
\hline 30 & アレドロン酸 (錠) & 60 & 骨粗鬆症 & 抜菌 & なし & ペニシリン（PO） & 治療中 & - \\
\hline
\end{tabular}

定することが必要であると考える，しかしながら，本調査 に扔いては定義ならびに診断基準は各施設に委ね，各施設 にて BP と関連性があると診断された顎骨骨䯣炎または骨 壞死の症例に関して調査を行った.

Dunstan ら ${ }^{11)}$ は，BP 投与と関連性があると考えられる 顎骨壊死患者を文献的に集計し，男女の発症数はほぼ等し いとしている，本調査に打いては，男女比は 1：6.5 と女 性に圧倒的に多く認められた。本邦に打いては本調查が施 行された 2006 年 4 月までの時期においては，保険適応上， BP が投与された患者の原疾患は，乳癌の溶骨性骨転移症 例，悪性腫瘍による高カルシウム血症ならびに骨粗鬆症が 主体であった。乳癌ならびに骨粗鬆症は女性に多い疾患で あり，BPの投与を受けた患者が女性に多いことが影響し たと推察される. 2006 年 4 月より，ゾレドロン酸注射薬が 多発性骨髄腫による骨病変および固形癌骨転移による骨病 変においても使用可能となり，今後は男性においても本病 態の発生数が増える可能性があると予測される.
罹患顎骨に関しては，諸家の報告ともに上顎骨と比較し 下顎骨に好発するとしている ${ }^{6 \sim 9)}$. 本調査においても，上 下顎ともに罹患した 2 例を加えると 24 症例において下顎 骨に病変が認められた。 Farrugia ら ${ }^{12)}$ は，BPによる顎骨 壊死と同様に，骨への血液供給が不足することにより生じ る放射線骨壊死と比較し，上顎骨の頻度が高いことを指摘 している. BPによる顎骨壊死に扔いては，放射線骨壊死と 比較し高圧酸素療法の効果が不良であることが指摘されて おり，放射線骨壊死と本病態は異なった機序にて発生する ことが示唆される.

Ruggiero ら ${ }^{6)}$ は, 典型的な臨床症状は, 抜菌した部位の 疼痛と骨露出としている。その他，柬肉腫脹など柬周組織 の変化, 原因が不明瞭な歯肉の感染, 治癒傾向が認められ ない粘膜潰瘍, 膿瘍または瘻孔形成, 義歯性潰瘍, 周囲軟 組織の炎症を伴った骨露出, 歯の動摇, 歯肉の修復機能低 下，顎骨のしびれ感，倦急感などが挙げられている ${ }^{13)}$. 本 調査においては，本病態に特徵的であるとされている骨露 
出が 19 症例に認められた。 その他の症状として, 疼痛, 腫 脹, 排膿, 出血, 下唇の知覚麻痺などがみられ, 既報告と同 様の傾向を示した，画像所見に打いては，骨吸収像，腐骨 形成，骨硬化像，虫食い像など，臨床症状ともに一般的な 顎骨骨髄炎，骨壊死と同様のものであった.すなわち，臨 床所見，画像診断所見ともに本病態に特異的な所見に之し く, 診断を下す際には BP 系薬剤の投薬の有無に関する情 報が重要であると考える.

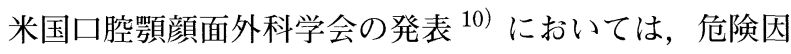
子として併用薬ならびにその他の因子が挙げられている. すなわち, 副腎皮質ステロイド薬の投与, 糖尿病, 喫煙, 飲 酒, 不良な口腔衛生状態, 抗癌薬の投与を挙げている. 本 調査においては, 併用薬が記載されていた 22 症例のなか で，抗癌薬，副腎皮質ステロイド薬はそれぞれ 10 症例，4 症例に投与されていた。一方，口腔衛生状態においては， 普通と判断された症例が多く，その関連性は不明である. 糖尿病に関しては，顎骨壊死を生じた患者の約 6 割が糖尿 病に罹患していたとの報告があり，一般的な糖尿病の罹患 率と比較し, 高頻度であることが指摘されている ${ }^{14)}$. 本調 査においては，糖尿病の罹患の有無は不明である。しかし ながら，一般的に糖尿病患者においては，代謝不全，易感 染性などにより顎骨壊死の症状の増悪, 重篤化する可能性 があると予測され，日常臨床において注意する必要がある と考える.

$\mathrm{BP}$ 製片にはさまざまな薬剤があり, 投与経路は静脈投 与ならびに経口投与がある. Marx ${ }^{2)}$ は, 薬剤別の発現頻 度を集計し，ゾレドロン酸（静注）投与，パミドロン酸 (静注) からゾレドロン酸へ変更投与, パミドロン酸投与 の順で発現頻度が高く，アレンドロン酸（経口）に扔いて は少数例 $(2.5 \%)$ であったとしている. 薬剤別に検討し

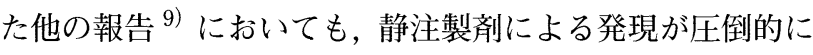
多い傾向がある. 本調査結果に打いては, 経口薬のみの投 与で発症した症例が 8 症例 $(26.7 \%)$ と, 他の報告と比較 し多い傾向が認められた。

一方，BP 投与開始から骨露出が認められるまでの期間は， 6 か月から 77 か月と報告によりまちまちである ${ }^{8,13,15 １ 7) . ~}$ 本調査においても，3 か月から 68 か月と症例により大きな 差がみられた。 BP 製剤の体内への吸収，骨吸収抑制能が， 製剂によりさまざまであること ${ }^{18)}$ が，投与開始から症状 発現までの期間が症例により大きく異なることの一因であ ると考える。

Marx ${ }^{2)}$ は，顎骨壊死の発症の契機と考えられた茵科疾 患または処置として, 抜柬, 進行した歯周病, 柬周外科処 置, インプラント体埋入，根管治療などを挙げている. Mavrokokki ら ${ }^{9)}$ は, 抜菊が最も多く, 義菊が関連したと 考えられる症例ならびに下碩骨骨折を契機とした症例があ
ったとしている，本調査においても，過半数の症例におい て抜蒾, インプラント体埋入, 義茵装着, 根管治療, う蝕処 置などが施行されていた。すすおち, 蒾科治療が頴骨壊死 の発現に関与している可能性が高いと考えられる。一方， Merigo ら ${ }^{19)}$ は, 発症した際に全例とも総義茵を装着して おり，明らかな義柬による外傷は認められず，危険因子と 考えられる要因もなかったとしている. Ruggiero ら ${ }^{6)}$, Mavrokokki ら ${ }^{9)}$ は，それぞれ $14.0 \% ， 21 \% の$ 症例におい て, 明らかな原因と考えられる茵科的治療, 疾患が認めら れなかったと報告している。本調查に执いては 5 症例 (16.7\%) に打いて，柬科治療歴はなかった。そのなかで， 2 症例が抗癌薬，1症例に扎いて副腎皮質ステロイド薬の 投与が行われていた. 4 症例の BP 系薬郕の投与より症状 発現までの期間は, 3 か月から 24 か月であり, 他の症例と 比較し, 明らかに長期間の投与が行われている傾向は認め られなかった.さらに， 口腔清掃状態が良好であった症例 が 1 症例, 普通と判断された症例が 3 症例, 不良が 1 症例 で，口腔清掃状態との関連性も認められなかった．以上よ り，明らかな顎骨への侵襲ならびに㐘槽部の炎症がないに もかかわらず, 発症した症例が認められることより, BP 系

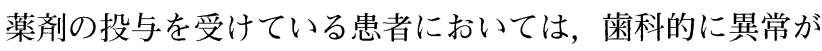
ない場合においても定期的に口腔内を観察しておく必要が あると考える.

BPの使用理由について, Dunstan $~^{11)}$ は文献的に集計 を行い, 多発性骨髄腫が $55.9 \%$ と最も多く, 乳癌が $33.4 \%$, 前立腺癌が $4.6 \%$ と 9 割以上の症例が悪性腫瘍と 関連して投与され，骨粗鬆症は $2.8 \%$ であたとしている. Mavrokokki ら ${ }^{9)}$ は，72\%が悪性腫瘍の骨転移ならびに多 発性骨髄腫すなわち骨の悪性腫瘍であり, $23 \%$ 骨粗鬆症 であったとしている，本調査においては，覀性腫瘍の治療 のために投与された症例は 22 症例であった。そのなかで， 多発性骨髄腫ならびに乳癌, 肺癌などの骨転移が 21 症例, 肺癌による高カルシウム血症が 1 症例であった。一方，骨 粗鬆症の治療を目的に処方された症例は 8 症例 $(26.7 \%)$ で，オーストラリアにおける集計 ${ }^{9)}$ と同様の傾向を示し た.これらの疾患を有する患者に対し㐘科治療を行う際に は，投薬内容の確認を十分に行い，対処する必要があると 考える.

顎骨壊死に対する処置，治療は，未だ有効な方法が確立 されていない，抗菌薬としては，アモキシシリン，ペニシ リンアレルギーがある場合には, クリンダマイシン, エリ スロマイシン，アジスロマイシンが選択される ${ }^{18)}$. 本調査 に扎いても，抗菌薬の投与の有無が不明な 4 症例を除き， ペニシリン系，セフェム系，マクロライド系抗菌薬が中心 に投与されていた．外科的処置としては，Marx ら ${ }^{7)}$ は， デブリッドマン, 粘膜弁による露出骨の被覆, 骨削除など 
の処置は, 多くの場合逆効果となり, さらに骨露出範囲の 拡大，症状の増悪，病的骨折を招く可能性があるとしてい る. Ruggiero ら ${ }^{6)}$ は, 局所麻酔下でのデブリッドマンを試 みた症例の大半は罹患骨の切除が必要となり, さらに，高 圧酸素療法も効果がなかったと報告している。したがって， 顎骨壊死ならびに骨露出が認められても，無症状の場合に は経過観察を行い，局所の洗浄など保存的な治療を推奨す るとしている. 米国口腔顎顔面外科学会は, 健常骨を露出 させない程度に可動性の腐骨を除去すること，全身的に許 容されるのであれば，BP 製剤の投与を中止することを推 奨している ${ }^{10)}$. しかしながら, BP 製剤, 特に静脈内投与が なされている際には，投与を中止した場合の，危険性なら びに有益性に関して，口腔外科医ならびに患者と相談の上， 当該腫瘍の治療を行っている腫瘍専門医が判断すべきであ るとしている. 本調查においては, 治療法が不明な 11 症例 ならびに治療を行わなかった 2 症例を除いた 17 症例にお いて，何らかの外科的治療が施行されていた．本調査にお いては，転帰が治癒の 8 症例のなかで， 7 症例において腐 骨除去がなされており, 現時点においては, 腐骨が分離し た症例においては，腐骨除去は妥当な治療法であると考え られる。しかしながら，3症例においては最終的に上顎骨 部分切除，下顎骨辺縁切除がなされており，腐骨除去を行 っても極めて治療に抵抗性であったと推察される。したが つて，治療方針の決定，特に外科的処置を施行する際には， 細心の注意が必要であると考える.

以上の如く， BP 製剤を投与中の患者における顎骨骨䯣 炎・顎骨壊死は，その予防法ならびに治療法ともに未だ確 立されていない.さらに発生頻度に関しても，オーストラ リアの報告 ${ }^{9}$ )を除き，母数である BP の投与を受けた総患 者数が明らかでなく, 把握できていないのが現状である. 治療に関しては，近年副甲状腺ホルモンを用いた治療法の 症例報告がなされている ${ }^{20)}$ が，その適応は骨粗鬆症の症 例に制限されたものであり，悪性腫瘍と関連した症例にお いては，使用は禁忌とされている．今後，本邦においても， 日常の歯科口腔外科臨床に打いて, 本病態に遭遇する機会 は増えることが予測される。したがって，予防，治療に対 する基礎的ならびに臨床的検討が早急に望まれる.

\section{結 語}

2006 年 4 月に全国の（社）日本口腔外科学会指定研修 機関を対象としたビスフォスフォネート系薬剤投与と関連 性があると考えられる顎骨骨髄炎ならびに顎骨壊死に関し て調査を行い, 以下の結果を得た.

1） 239 施設にアンケート調查を実施し，25 施設より顎 骨病変の記載があった 30 症例を集計の対象とした.
2）男女比は $1 ： 6.5$ で女性に多く, 平均年齢は 66.9 歳, 罹患顎骨は上顎骨のみが 6 症例, 下顎骨のみが 22 症例, 上 下䯪骨が 2 症例であった。

3）臨床症状としては, 疼痛, 腫脹が大半の症例に認めら れた，骨露出が認められた症例は 19 症例であった．画像診 断に打いては，腐骨形成を認めた症例が 9 症例と最も多く， その他, 骨吸収像, 骨硬化像, 虫食い像などが認められた。

4）薬凰別にはパミドロン酸ナトリウム水和物（注射薬） が 16 症例，インカドロン酸ナトリウム（注射薬）が 9 症 例と続いた。 一方, 経口薬のみを投与された症例は 8 症例 であった. 投与開始から発症までの平均期間は 26.5 か月で あった。

5）19症例においてビスフォスフォネート投与中に菌科 治療が施行されていた. 抜柬が 16 症例と最も多かったが, ブリッジ装着, 義柬装着など柬科補綴的処置も含まれてい た.

6）ビスフォスフォネートの使用理由は悪性腫瘍，特に 乳癌の骨転移が最も多かった.

7）処置は, 大半の症例に打いて抗菌薬の投与が行われ ており,さらに, 腐骨除去, 病変部の掻爬などの外科的処 置が施行されていた。

8）転帰は, 治療中の症例が多く, 治癒は 8 症例であっ た.

謝辞

本調査の遂行にご協力頂きました（社）日本口腔外科学会 指定研修機関各施設の代表者, 各位ならびに（社）日本口腔 外科学会事務局各位に深謝いたします。また御高閲を賜りま した（社）日本口腔外科学会理事長 瀬戸晥一教授に深謝いた します.

\section{引用 文 献}

1) Wang, J., Goodger, N.M., et al.: Osteonecrosis of the jaws associated with cancer chemotherapy. J Oral Maxillofac Surg 61: 1104-1107 2003.

2) Marx, R.E.: Pamidronate (Aredia) and Zoledronate (Zometa) induced avascular necrosis of the jaws: A growing epidemic. J Oral Maxillofac Surg. 61: 111511182003.

3）高橋喜久雄, 川畑彰子, 他：ビスフォスフォネート によって発症したと考えられた上顎骨壊死の 1 例. 日口外誌 52: 416-419 2006.

4）岸 直子, 足立忠文, 他：ビスフォスフォネートに より発症した下顎骨壊死の 1 例. 日口外誌 53: 28-32 2007.

5) Thron, J.J., Hansen, H.S., et al.: Osteoradionecrosis of the jaws: Clinical characteristics and relation to the field of irradiation. J Oral Maxillofac Surg. 58: 1088 2000. 
6) Ruggiero, S.L., Mehrotra, B., et al.: Osteonecrosis of the jaws associated with the use of Bisphosphonates: A review of 63 cases. J Oral Maxillofac Surg. 62: 5275342004.

7) Marx, R.E., Sawatari, Y., et al.: BisphosphonateInduced exposed bone(Osteonecrosis/Osteoporosis) of the jaws: risk factor, recognition, prevention, and treatment. J Oral Maxillofac Surg 63: 1567-1575 2005.

8) Ficarra, G., Beninati, F., et al.: Osteonecrosis of the jaws in periodontal patients with a history of bisphosphonates treatment. J Clin Periodontol 32: 1123-1128 2005.

9) Mavrokokki, T., Cheng, A., et al.: Nature and frequency of Bisphosphonate-Associated osteonecrosis of the jaws in Australia. J Oral Maxillofac Surg. 65: 415-423 2007.

10) Advisory Task Force on Bisphosphonate-Related Ostenonecrosis of the Jaws: American Association of Oral and Maxillofacial Surgeons Position Paper on Bisphosphonate-Related Osteonecrosis of the Jaws. J Oral Maxillofac Surg 65: 369-375 2007.

11) Dunstan, C.R., Felsenberg, D., et al.: Therapy Insight: the risks and benefits of bisphosphonates for the treatment of tumor-induced bone disease. Nat Clin Pract Oncol 4: 42-55 2007.

12) Farrugia, M.C., Summerlin, D.J., et al.: Osteonecrosis of the mandible or maxilla associated with the use of new generation bisphosphonates. Larygoscope 116: 115-120 2006.

13) Purcell, P.M. and Boyd, I.W.: Bisphosphonate and osteonecrosis of the jaw. Med J Australia 182: 417-418 2005.

14) Khamaisi, M., Regev, E., et al.: Possible association between diabetes and Bisphosphonate-related jaw osteonecrosis. J Clin Endocrinol Metab 92: 1172-1175 2007.

15) Zarychanski, R., Elphee, E., et al.: Osteonecrosis of the jaw associated with Pamidronate therapy. Am J Hematol 81: 73-75 2006.

16) Bagan, J.V.: Jaw osteonecrosis associated with bisphosphonates: Multiple exposed areas and its relationship to teeth extractions. Study of 20 cases. Oral Oncol 42: 327-329 2006.

17) Gibbs, S.D.J., Grady, J.O., et al.: Bisphosphonateinduced osteonecrosis of the jaw requires early detection and intervention. Med J Australia 183: 5495502005 .

18）浦出雅裕：ビスホスホネートと顎骨壊死. Clinical Calcium 17: 241-248 2007.

19) Merigo, E., Manfredi, M., et al.: Jaw bone necrosis without previous dental extractions associated with the use of bisphosphonates (pamidronate and zoledronate): a four-case report. J Oral Pathol Med 34: 613-617 2005.

20) Harper, R.P and Fung, E.F.: Resolution of Bisphosphonate-associated osteonecrosis of the mandible: Possible application for intermittent low-dose parathyroid hormone (rhPTH (1-34). J Oral Maxillofac Surg 65: 573-580 2007. 